7-15-2020

\title{
Effects of COVID-19 on livelihood, employment, and financial resources
}

UNICEF

Population Council Institute

Follow this and additional works at: https://knowledgecommons.popcouncil.org/departments_sbsr-pgy

Part of the Demography, Population, and Ecology Commons, International Public Health Commons, and the Public Health Education and Promotion Commons How does access to this work benefit you? Let us know!

\section{Recommended Citation}

UNICEF and Population Council Institute. 2020. "Effects of COVID-19 on livelihood, employment, and financial resources," COVID-19 Research Results Brief \#8. New Delhi: UNICEF and Population Council Institute. 
EFFECTS OF COVID-19 ON LIVELIHOOD, EMPLOYMENT, AND FINANCIAL RESOURCES

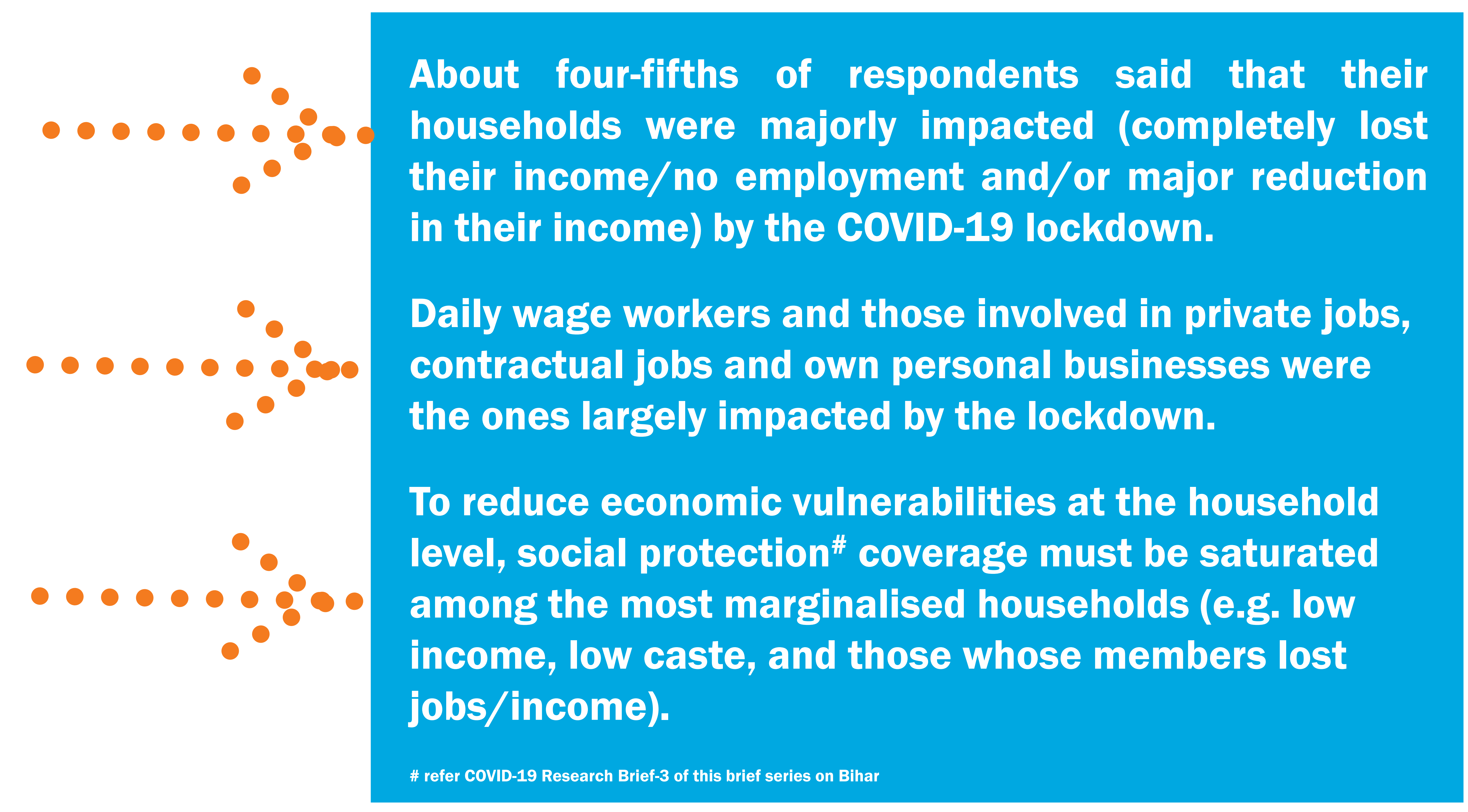

EFFECT ON EMPLOYMENT AND FINANCIAL RESOURCES

\section{BACKGROUND}

COVID-19 and related steps to break the chain of viral transmission led to certain economic challenges that triggered loss in livelihood and income and constraints on financial resources. Often, these effects were disproportionately experienced among the most marginalised.

The key objective of this study is to assess the loss of income, livelihoods and jobs among households in Bihar to help programme planning and implementation.

\section{METHODS}

- Data was gathered between May 13-22, 2020 from the existing study cohort of households under the UDAYA (www.projectudaya.in) study.

- Interviews were conducted with a total of 794 participant households in the study.

- Eligibility: Young boys/girls who were UDAYA participants, consented to participate in the regular surveys.

\section{PROFILE OF STUDY PARTICIPANTS}

\begin{tabular}{|c|c|c|c|}
\hline & $\begin{array}{r}\mathrm{N}=794 \\
\text { Percent }\end{array}$ & & $\begin{array}{r}\mathrm{N}=794 \\
\text { Percent }\end{array}$ \\
\hline Sex & & Place of residence & \\
\hline Male & 31 & Urban & 38 \\
\hline Female & 70 & Rural & 62 \\
\hline Age & & Caste & \\
\hline $18-20$ years & 38 & $\mathrm{SC} / \mathrm{ST}$ & 16 \\
\hline $21-25$ years & 53 & $\mathrm{OBC}$ & 64 \\
\hline$>25$ years & 09 & General & 20 \\
\hline Education & & $\begin{array}{c}\text { Religion } \\
\text { Hindu }\end{array}$ & \\
\hline Less than secondary & 35 & Muslim & 14 \\
\hline Secondary and above & 66 & Standard of livino* & \\
\hline Marital status & & $\begin{array}{l}\text { Sow } \\
\text { Lowa or Ilving }\end{array}$ & 14 \\
\hline Married & 54 & Medium & 14 \\
\hline Unmarried & 46 & High & 72 \\
\hline
\end{tabular}

\section{*SL is a tertial measure calculated based on the wealth score of UDAYA wave-1 study. The current sample is a
subset with a working mobile phone and consented to be interviewed at this time.}

\section{EFFECT ON EARNING}

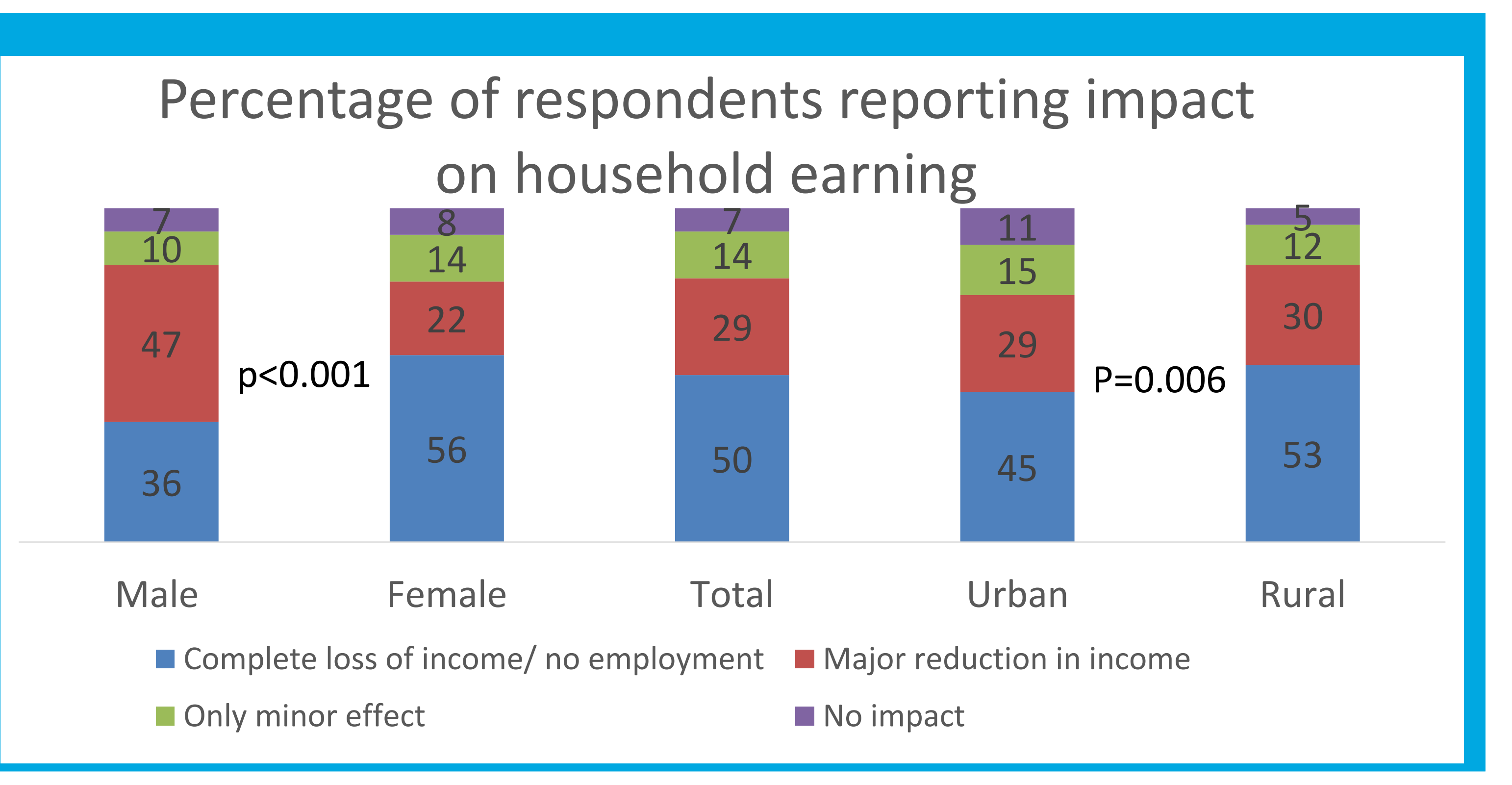

- The proportion of respondents experiencing either major reduction or complete loss of earnings was substantial, irrespective of sex or residence in rural or urban areas. A greater proportion of female participants than male participants reported complete loss of income or no employment during the lockdown.

\section{Type of jobs/work lost owing to lockdown

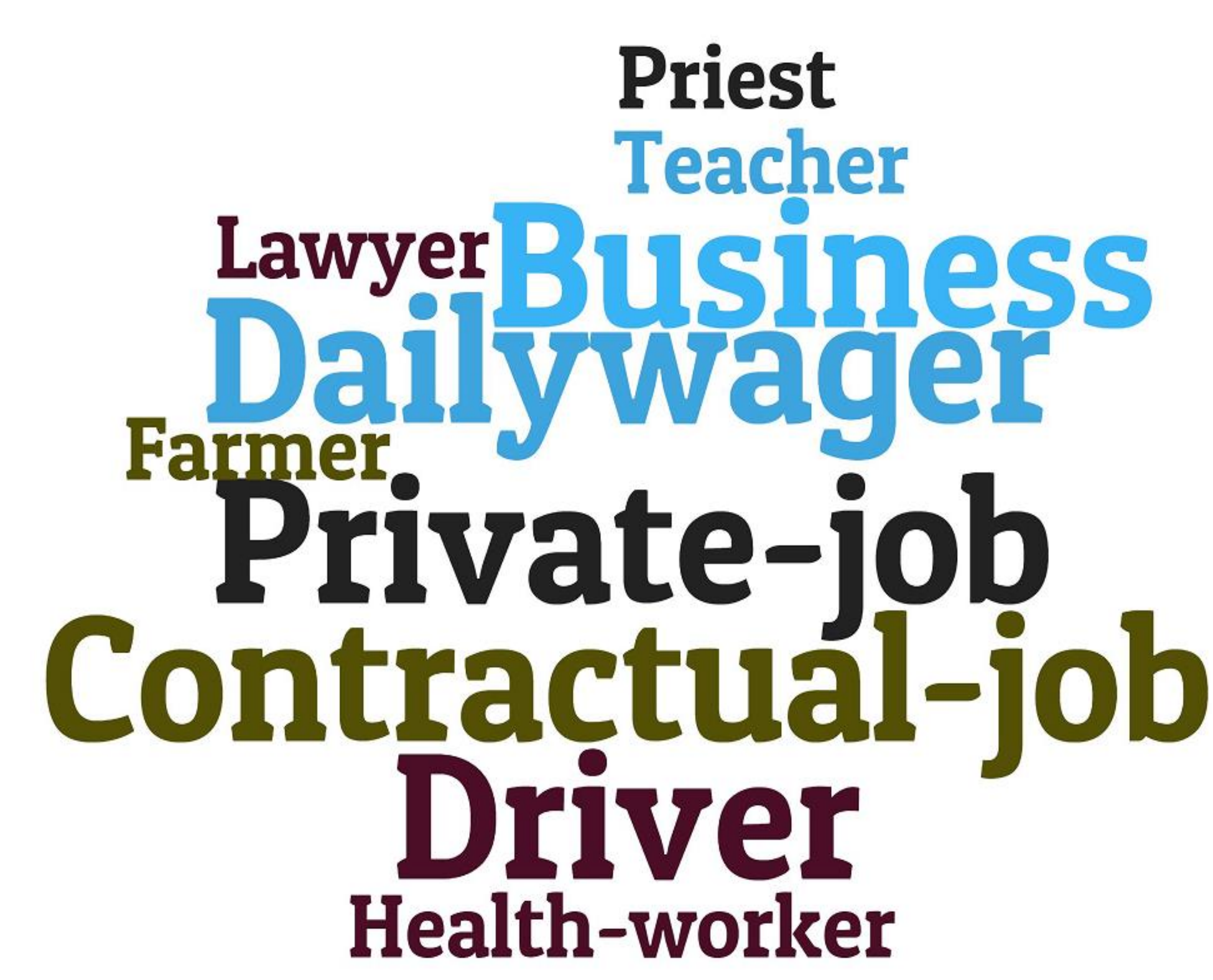

Members in about two-thirds of households (64\%, 95\% Cl: 61\%-67\%) lost their job/wages because of the lockdown. Over half of those who lost their job/wages were earlier working as daily wage workers (54\%, 95\% Cl: 50\%-58\%) ), while those in private jobs and personal businesses constituted 26\% (95\% Cl: 23\%-30\%) each.

- Respondents from the most marginalised households, i.e. those belonging to SC/ST and low-income households, experienced significant loss of job or wage-earning opportunities due to the lockdown. They also reported that their financial resources were sufficient for only less than a month.

Majority of the households with members having complete loss of income or major reduction in income or loss of job reported that they faced severe constraints on the length of time that their financial resources would last (65\%, 95\% Cl: $61 \%-68 \%)$

\section{EFFECT ON EARNING (CONTD.)}

Complete loss of income has been significantly more among low/medium-income households than high-income households. Close to nine-tenths of low/medium-income households experienced major or complete loss of income as against eight-tenths of high-income households.

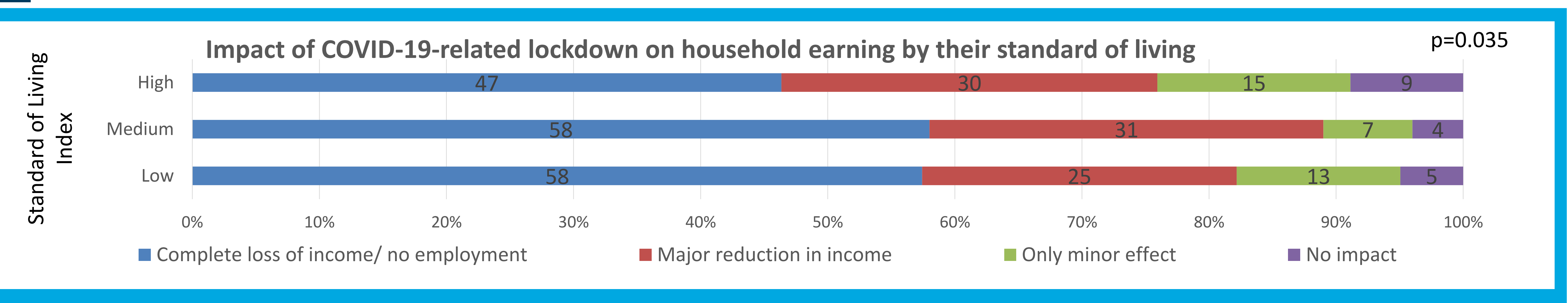

\section{LIMITATIONS}

Although the study sample is a subset of the state-representative UDAYA SDG cohort of adolescents, the representative nature of the selection could not be retained because of differential phone ownership by adolescents from higher and lower economic strata, mobile number retention/ portability, etc. However, the levels noted in the current study on loss of job, income and financial resources perhaps represents as underestimates for general population in the state.

\section{CONTACT INFORMATION}

This work was jointly undertaken by Population Council Institute and UNICEF/Bihar. For more information, contact skpatel@popcouncil.org ; pash@unicef.org 